\title{
Achieving self-definition
}

The Lily Pond: A Memoir of Madness, Myth and Metamorphosis

Mike Barnes

Biblioasis; 2008.192 pp \$19.95

$\mathrm{M}$ emoirs of madness are now part of a tradition: There's Andrew Solomon's overrated The Noonday Demon; William Styron's excellent little squib Darkness Visible; and for a description of the utter nonsensical terrifying rhythms of psychosis nothing beats Mark Vonnegut's The Eden Express.

The best of these books (I have listed but a few) all grapple with similar themes: the urge to kill oneself; the conundrum of whether the illness is in fact an illness or if it is part of one's psychological makeup and whether the illness is wedded to creativity; the journey to diagnosing the illness; and the struggle to find the right drug, the right doctor, the right mate. What distinguishes the best of these books - all rather grim itemizations of what a serious mental illness can do to the body and soul — is the quality of the writing.

Barnes' prose is spare, lyrical: a very mirror to desolation, to erasure. It is as if you are having coffee with a stranger, and he is telling his tale without self-pity or gloom. The teller is compelling not because of his experience of survival (this is emphatically not a self-help, inspirational, or therapy book), but because of his assertion of the illness, his inhabitation of it and his portrayal of madness.

This illness is relentless and although Barnes does not do anything so obvious, it can be likened to an implacable force of nature, pressingly present, incrementally receding, then massing off the coast. This is assuredly a key factor in the value of this memoir: if there were resentment at the cost of illness, we'd have another whine book and the power of the tale would succumb to an undertow.

There is one, and thankfully not fatal, structural mistake. Barnes opens the

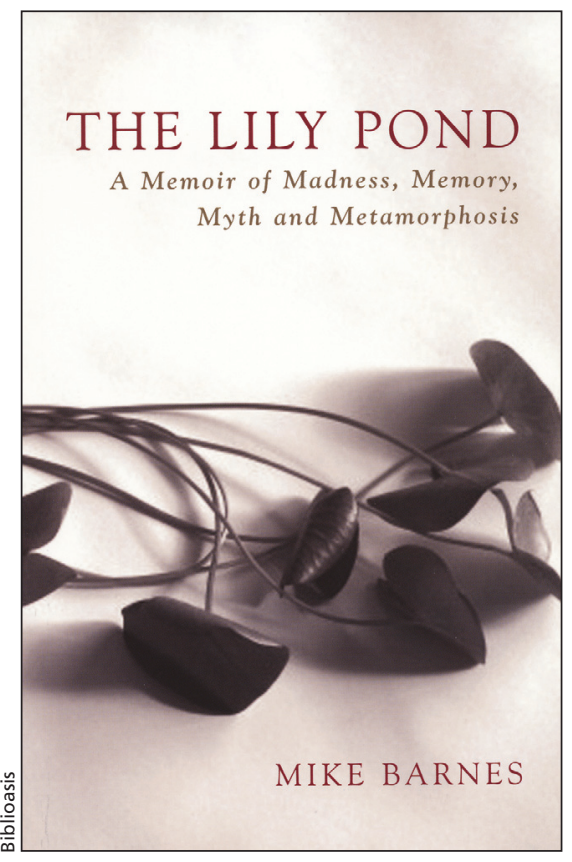

book with the death scene. This really is the cliché of the genre. It is a kind of lazy shorthand to establish stakes that should be achieved by other means. Death is a subject that such books must be honest about and must mention, but not at the outset. And Barnes stretches it out over an entire long chapter. Things are not aided later by the cliché of all clichés: "Two images occur to me ...[a] candle dwindling down to its final stub. It will soon go out, but for now, the flame around the wick still flickers...." A conventional chapter about his childhood might have better served as an introduction. Instead, we immediately say hello-in-extremis to an eloquent $\mathrm{Mr}$. Death, to a deworded Mr. Zapped (and to complete the unholy trinity, masturbation is also mentioned).

Outside of the first chapter, however, he is less self-absorbed; there are no flourishes, there is just purpose, and Barnes takes interest in all the characters of his life. Memoirs can sometimes lose themselves at the exact location of their navels, and Barnes' self-knowledge prevents that, despite the occasional tinkling piano key, like the too-pregnant set piece at the psychiatrist's office when Barnes is told he can recover: "It was a hard message to hear in some ways. The tears that started to my eyes felt like droplets of rain after a massive drought. Were they harbingers of the real downpour needed, or just a tantalizing sprinkle?"

And what of the outcome? Barnes is unsentimental about this when he reflects on the occasion of a birthday party: "Thirty-three years lay between this late afternoon, slowly dimming now, pooling its shadows toward dusk...[u]nvanquishable, he must have seemed - and apparently still does sometimes, uncannily, some core of myth intact despite the more than 3 decades of precipitous falls and long slow climbs, slides and wily scalebacks, according to some persistence of family memory and personal meaning..." It is this mixed feeling, this summation of both bipolar disorder as what he has and what he has lost, that is the mythic core of this book, the dualism, and hence its value.

Barnes is a star gazer, a wanderer of the imagination, and uncompromisingly honest with his own story. This is the real service he offers for those looking for more than self-help: he offers self-definition without romance or servile hope. Barnes considers himself both adaptive and maladaptive. And you root for him as he severs the selfimage of illness, the switcheroo of the identity of illness. At some point in all of the madness memoirs, stock must be taken, house cleaned: The Lily Pond is that clearinghouse. One gets the double sense that Barnes, as he works out his own illness' feints and predilections, is free as he never will be free.

\section{Shane Neilson MD \\ Family physician \\ Guelph, Ont.}

Dr. Neilson's first book of poetry, Exterminate My Heart, was published in 2008 by Frog Hollow Press. His second collection, My Manic Statement, a book of poems about bipolar disorder, is slated to be published in 2009 by Biblioasis. 